Jurnal Ilmu Ilmu Agribisnis: Journal of Agribusiness Science, 9(3), Agustus 2021

\title{
KETAHANAN PANGAN RUMAH TANGGA PETANI KOPI DI KECAMATAN ULU BELU KABUPATEN TANGGAMUS
}

\author{
(Food Security Level of Coffee Farmer Households in Ulu Belu \\ Subdistrict of Tanggamus Regency)
}

Elok Dinar Anggitasari, Yaktiworo Indriani, Fembriarti Erry Prasmatiwi

\begin{abstract}
Jurusan Agribisnis, Fakultas Pertanian, Universitas Lampung, Jl. Prof. Dr. Soemantri Brodjonegoro No. 1 Bandar Lampung 35145, e-mail: yaktiworo.indriani@fp.unila.ac.id
\end{abstract}

\begin{abstract}
The aims of this research are to analyze the level of food security, the factors that affect the level of food security, and efforts to increase the level of food security of coffee farmer households. The method used in this research is a survey method. Location is chosen purposively in Ngarip and Sukamaju Villages, Ulu Belu Subdistrict, Tanggamus regency with samples of 70 coffee farmer households selected using a simple random method. The data were primary and secondary data, collected in May - July 2018 and analyzed by cross-table between the share of food expenditure and energy adequacy level, ordinal logistic regression, and descriptive qualitative analysis. The results of the research according to BPS showed that the majority of respondents belonged to the category of food secure (31.43\%), and the rest belonged to the category lack of food (30.00\%), food vulnerable (22.86\%), food insecure (15.71\%). The results according to nutrition and 2012 food law showed that the majority of respondents belonged to the category of food security (50.00\%), lack of food (41.43\%), food vulnerable (5.71\%), and food insecure (2.86\%). The affecting factors on the level of food security were the household income and education level of housewives. The efforts to increase the level of food security by Government were conducted by monitoring of food availability and food reserves, developing food distribution and stabilization of food prices, developing diversification of consumption and food security as well as staple food assistance through the raskin program, whereas efforts are carried out by households coffee farmers, namely by doing productive activities outside the coffee farm.
\end{abstract}

Key words: coffee farmer households, food expenditure, food security

\section{PENDAHULUAN}

Provinsi Lampung merupakan salah satu penghasil kopi terbesar di Indonesia. Kabupaten Tanggamus merupakan kabupaten yang memiliki jumlah produksi kopi terbesar kedua di Provinsi Lampung yaitu sebesar 42.667 ton. Selain itu Kabupaten Tanggamus juga menempati urutan kedua di Provinsi Lampung dengan produktivitas sebesar 0,98 ton/ha (Badan Pusat Statistik Provinsi Lampung 2017). Pada tahun 2016, Kecamatan Ulu Belu merupakan kecamatan terbesar sebagai sentra kopi di Kabupaten Tanggamus dengan produksi sebesar 11.577 ton dan luas areal lahan sebesar 10.786 hektar karena di Kecamatan Ulu Belu sebagian besar penduduknya adalah petani kopi.

Produksi kopi yang tinggi di Kecamatan Ulu Belu berpengaruh terhadap tingkat pendapatan rumah tangga petani kopi dan juga menjadi salah satu faktor dalam menentukan tingkat ketahanan pangan rumah tangga. Semakin rendah produksi kopi maka pendapatan yang diperoleh juga akan semakin rendah, begitu pula sebaliknya.
Rendahnya pendapatan rumah tangga petani akan menentukan jenis dan jumlah pangan yang dikonsumsi dan secara tidak langsung akan berpengaruh pada tingkat ketahanan pangan rumah tangga petani.

Undang-Undang Republik Indonesia Nomor 18 tahun 2012 mendefinisikan ketahanan pangan sebagai kondisi terpenuhinya pangan bagi negara sampai dengan perseorangan, yang tercermin dari tersedianya pangan yang cukup baik jumlah maupun mutunya, aman, beragam, bergizi, merata, dan terjangkau serta tidak bertentangan dengan agama, keyakinan, dan budaya masyarakat untuk dapat hidup sehat, aktif dan produktif secara berkelanjutan.

Kecamatan Ulu Belu Kabupaten Tanggamus merupakan daerah yang berada pada dataran tinggi sehingga menjadi salah satu kendala dalam akses untuk mendapatkan pangan. Akses pangan yang rendah menyebabkan ketidakpastian rumah tangga dalam mencapai kondisi kecukupan pangan (food sufficient), jaminan pangan (food security), serta 
keberlanjutan pangan (food sustainability). Kecamatan Ulu Belu bukanlah daerah penghasil pangan pokok beras sehingga rumah tangga biasanya memperoleh pangan melalui pembelian. Menurut Anggraini, Zakaria dan Prasmatiwi (2014), distribusi pangan diukur dari cara rumah tangga dalam mengakses pangan apakah secara langsung atau tidak langsung. Kecamatan Ulu Belu merupakan daerah yang berada pada dataran tinggi sehingga menjadi salah satu kendala dalam akses untuk mendapatkan pangan.

Tingkat ketahanan pangan suatu wilayah dapat diukur dari ketersediaan pangan, daya beli dan tingkat konsumsi penduduk. Tingkat konsumsi pangan dapat memberikan gambaran kondisi kesehatan penduduk di suatu wilayah ditinjau dari aspek keadaan gizi. Indikator yang digunakan untuk analisis konsumsi pangan yaitu dari pengukuran kecukupan energi dan protein (Saputri, Lestari dan Susilo 2016). Ketahanan pangan yang baik juga dipengaruhi oleh beberapa faktor antara lain tingkat pendidikan ibu rumah tangga, tingkat pendapatan rumah tangga petani, jumlah anggota rumah tangga, dan harga sembako (Anggraini et al. 2014).

Perlu dilakukan upaya dalam meningkatkan atau mempertahankan ketahanan pangan. Pemerintah membuat Rencana Strategis Badan Ketahanan Pangan tahun 2015-2019 sebagai upaya pelaksanaan pembangunan ketahanan pangan yang bertujuan untuk mewujudkan pemantapan ketahanan pangan masyarakat sampai tingkat perseorangan secara berkelanjutan mengenai pengembangan ketersediaan, penanganan rawan pangan, sistem distribusi, stabilitas harga pangan, pengembangan penganekaragaman konsumsi pangan dan keamanan pangan. Penelitian ini bertujuan untuk menganalisis tingkat ketahanan pangan rumah tangga petani kopi, yang kedua menganalisis faktor-faktor yang memengaruhi tingkat ketahanan pangan rumah tangga petani kopi dan yang ketiga menganalisis upaya dalam meningkatkan atau mempertahankan ketahanan pangan rumah tangga petani kopi.

\section{METODE PENELITIAN}

Metode penelitian yang digunakan adalah metode survei. Populasi yang dijadikan sasaran dalam penelitian ini adalah rumah tangga petani kopi di daerah penelitian. Penelitian ini dilaksanakan di Kecamatan Ulu Belu Kabupaten Tanggamus yaitu di Desa Ngarip dan Sukamaju. Penentuan lokasi dilakukan secara sengaja (purposive) dengan pertimbangan bahwa kedua desa tersebut memiliki produktivitas kopi tertinggi dari seluruh desa yang ada di Kecamatan Ulu Belu. Pengumpulan data dilakukan pada bulan Agustus sampai September 2018.

Jenis data yang digunakan terdiri dari data primer dan sekunder. Data primer berupa wawancara langsung yaitu ada data ketersediaan, distribusi dan konsumsi pangan serta upaya yang dilakukan petani untuk mempertahankan ketahanan pangannya. Data sekunder berupa literature, dokumentasi, instansi terkait dan pustaka. Populasi dalam penelitian ini adalah 760 rumah tangga petani kopi dengan pengambilan sampel menggunakan metode simple random sampling. Penentuan jumlah sampel mengacu pada Issac dan Michael dalam Soegiarto (2003). Berdasarkan perhitungan diperoleh sampel sebanyak 70 responden rumah tangga petani kopi. Data konsumsi pangan dikumpulkan melalui metode recall (mengingat kembali) makanan yang dikonsumsi selama 24 jam yang lalu dan dilakukan sekurang-kurangnya dua atau tiga kali pada hari yang tidak berurutan.

Tujuan penelitian pertama adalah menganalisis tingkat ketahanan pangan rumah tangga petani kopi yang diukur dengan menggunakan indikator klasifikasi silang antara pangsa pengeluaran pangan dan kecukupan energi yang dikembangkan oleh Johnson dan Toole dalam Maxwell et al. (2000) yang dapat dilihat dalam Tabel 1. Angka Kecukupan Energi (AKE) individu dihitung berdasarkan berat badan menurut kelompok umur dan jenis kelamin.

AKE I $=\frac{\text { Berat badan altual (kg) }}{\text { Berat badan standar (kg) }} \times$ AKE I

Untuk mengetahui jumlah Angka Kecukupan Energi (AKE) Rumah Tangga maka dihitung dengan cara:

AKE RT $=\sum$ AKE $I_{i-n}$

Dalam Perdana dan Hardinsyah (2013), tingkat kecukupan energi (TKE) dirumuskan sebagai berikut:

TKE RT $=\frac{\text { Asupan energi RT }}{\text { Angka keculupan energi RT }} \times 100 \%$

Pangsa pengeluaran pangan dihitung dengan rumus sebagai berikut: 
$\mathrm{PPP}=\mathrm{PP} / \mathrm{T} \times 100 \%$

Keterangan:

$\mathrm{PPP}=$ Pangsa pengeluaran pangan $(\%)$

$\mathrm{PP}=$ Pengeluaran belanja pangan $(\mathrm{Rp} / \mathrm{bulan})$

$\mathrm{T}=$ Total pengeluaran rumah tangga $(\mathrm{Rp} / \mathrm{bulan})$

Tujuan penelitian kedua yaitu menganalisis faktorfaktor yang memengaruhi tingkat ketahanan pangan menggunakan regresi ordinal logit dengan persamaan sebagai berikut.

$$
\begin{aligned}
& \mathrm{Zi}=\operatorname{Ln}\left[\frac{P_{i}^{i}}{1-P i}\right]=\alpha+\beta_{1} X_{1}+\beta_{2} X_{2}+\beta_{3} X_{3}+\beta_{4} X_{4}+ \\
& \beta_{5} X_{5}+\beta_{6} X_{6}+\beta_{7} X_{7}+\beta_{8} X_{8}+\beta_{9} X_{9} \\
& +\mathrm{e} \text {. }
\end{aligned}
$$

\begin{tabular}{|c|c|c|}
\hline $\mathrm{Zi}$ & $=$ & $\begin{array}{l}\text { Peluang } \mathrm{Z} 1=\mathrm{Z}(\mathrm{Y}=1) \text { untuk rumah } \\
\text { tangga rawan pangan, Peluang } \mathrm{Z} 2 \\
\mathrm{Z}(\mathrm{Y}=2) \text { untuk rumah tangga rentan } \\
\text { pangan, Peluang } \mathrm{Z} 3=\mathrm{Z}(\mathrm{Y}=3) \\
\text { untuk rumah tangga kurang } \\
\text { pangan, Peluang } \mathrm{Z} 4=\mathrm{Z}(\mathrm{Y}=4) \\
\text { untuk rumah tangga tahan pangan }\end{array}$ \\
\hline $\mathrm{P}$ & $=$ & Peluang untuk menentukan tingkat \\
\hline & & $\begin{array}{l}\text { ketahanan pangan bila } \mathrm{Xi} \\
\text { diketahui }\end{array}$ \\
\hline$\alpha$ & $=$ & Intersep \\
\hline$\beta 1-\beta 9$ & $=$ & $\begin{array}{l}\text { Koefisien regresi parameter } \\
(i=1,2,3,4,5,6,7,8,9)\end{array}$ \\
\hline $\mathrm{X} 1$ & $=$ & $\begin{array}{l}\text { Pendapatan rumah tangga } \\
\text { (Rp/Bulan) }\end{array}$ \\
\hline $\mathrm{X} 2$ & $=$ & $\begin{array}{l}\text { Pendidikan ibu rumah tangga } \\
\text { (tahun) }\end{array}$ \\
\hline X3 & $=$ & $\begin{array}{l}\text { Jumlah anggota rumah tangga } \\
\text { (orang) }\end{array}$ \\
\hline $\mathrm{X} 4$ & $=$ & Harga beras $(\mathrm{Rp} / \mathrm{Kg})$ \\
\hline X5 & $=$ & Harga minyak goreng $(\mathrm{Rp} / \mathrm{L})$ \\
\hline X6 & $=$ & Harga tepung terigu( $\mathrm{Rp} / \mathrm{Kg})$ \\
\hline $\mathrm{X} 7$ & $=$ & Harga gula pasir $(\mathrm{Rp} / \mathrm{Kg})$ \\
\hline $\mathrm{X} 8$ & $=$ & Harga telur(Rp/Kg) \\
\hline X9 & $=$ & Harga ikan asin( $\mathrm{Rp} / \mathrm{Kg})$ \\
\hline $\mathrm{e}$ & $=$ & Error term \\
\hline
\end{tabular}

\section{Keterangan:}

\begin{tabular}{|c|c|c|}
\hline \multirow[b]{2}{*}{$\begin{array}{l}\text { Konsumsi Energi per } \\
\text { unit ekuivalen dewasa }\end{array}$} & \multicolumn{2}{|c|}{ Pangsa pengeluaran pangan } \\
\hline & $\begin{array}{c}\text { Rendah } \\
(<60 \% \\
\text { pengeluaran } \\
\text { total }) \\
\end{array}$ & $\begin{array}{c}\text { Tinggi }(\geq 60 \% \\
\text { pengeluaran } \\
\text { total) }\end{array}$ \\
\hline Cukup (>80\% ) & Tahan pangan & $\begin{array}{l}\text { Rentan } \\
\text { pangan }\end{array}$ \\
\hline Kurang $(\leq 80 \%)$ & $\begin{array}{l}\text { Kurang } \\
\text { pangan }\end{array}$ & Rawan pangan \\
\hline
\end{tabular}

Tabel 1. Kriteria tingkat ketahanan pangan rumah tangga
Estimasi model ordinal logit menggunakan uji Likelihood Ratio (LR) untuk mengetahui tingkat pengaruh seluruh variabel independen secara bersama-sama terhadap variabel dependen, nilai LR sama dengan Pseudo R2. Untuk menguji masing-masing variabel independen dilakukan $U j i$ Wald dengan cara membagi nilai dugaan peubah dengan simpangan bakunya. Uji Wald dilakukan untuk menguji pengaruh secara individu variabel independen terhadap variabel dependen. Uji Goodness of Fit untuk mengetahui seberapa baik model dalam menjelaskan hubungan antara variabel dependen dengan variabel independennya.

Pada regeresi logistik, koefisien determinasi (R2) yang digunakan adalah Mc-Fadden Rsquare. Tujuan penelitian ketiga yaitu menganalisis upaya dalam meningkatkan ketahanan pangan dianalisis secara deskriptif untuk mengetahui upaya yang dilakukan pemerintah dan rumah tangga petani kopi untuk meningkatkan ketahanan pangan.

\section{HASIL DAN PEMBAHASAN}

Mayoritas responden berusia antara 28 hingga 66 tahun. Mayoritas kepala keluarga dan ibu rumah tangga hanya menempuh pendidikan sampai tingkat Sekolah Menengah Pertama (SMP). Jumlah anggota rumah tangga petani kopi sebagian besar berkisar antara 3-4 orang dengan persentase 62,86 persen. Seluruh kepala keluarga berprofesi sebagai petani kopi namun masih ada yang mempunyai pekerjaan sampingan untuk menambah pemasukan dalam memenuhi kebutuhan keluarganya. Diantaranya, sebesar 10 persen sebagai buruh tani, 7,15 persen sebagai pedagang, 5,71 persen sebagai guru, dan PNS sebesar 8,57 persen. Pada (Tabel 2) pendapatan total rumah tangga per tahun adalah Rp53.900.936,73. Jika dikonversikan per bulan maka pendapatan total rumah tangga petani kopi sebesar Rp4.491.744,72.

Tabel 2. Total pendapatan rumah tangga petani kopi di Kecamatan Ulu Belu KabupatenTanggamus

\begin{tabular}{llrr}
\hline No & $\begin{array}{c}\text { Jenis Sumber } \\
\text { Pendapatan }\end{array}$ & $\begin{array}{c}\text { Pendapatan } \\
\text { (Rp) }\end{array}$ & $\begin{array}{c}\text { Kontribusi } \\
\text { Terhadap } \\
\text { Pendapatan } \\
\text { Rumah } \\
\text { Tangga (\%) }\end{array}$ \\
\hline 1 & $\begin{array}{l}\text { On Farm } \\
\text { (kopi dan } \\
\text { tumpang sari) }\end{array}$ & $46.580 .222,45$ & 86,42 \\
2 & Off Farm & $532.142,86$ & 0,99 \\
3 & Nonfarm & $6.788 .571,43$ & 12,59 \\
\hline & Jumlah & $53.900 .936,73$ & 100,00 \\
\hline
\end{tabular}




\section{Ketahanan Pangan Rumah Tangga}

\section{Ketersediaan pangan}

Ketersediaan pangan merupakan ketersediaan pangan dalam jumlah yang cukup aman dan bergizi untuk semua orang baik yang berasal dari produksi sendiri, impor, cadangan pangan maupun bantuan pangan. Dalam memperoleh pangan dilakukan dengan cara membeli dan tidak membeli. Tempat membeli bahan makanan bagi petani di Kecamatan Ulu Belu Kabupaten Tanggamus adalah pasar, toko dan juga di warung terdekat. Bahan pangan yang tidak membeli diperoleh dengan cara memproduksi pangan sendiri dari hasil memanfaatkan lahan di sekitar rumah dan juga memperoleh bantuan dari pemerintah.

Pangsa pengeluaran pangan dianalisis berdasarkan kriteria BPS dan Undang-undang Pangan tahun 2012. Komponen pengeluaran rumah tangga yang dianalisis sama yaitu berupa pengeluaran pangan dan nonpangan hanya berbeda pada penempatan pengeluaran rokok. Persentase total pengeluaran pangan untuk kategori BPS lebih besar, karena adanya rokok. Hal ini didukung oleh penelitian Sugesti MT, Abidin Z, dan Kalsum U (2015), besarnya pengeluaran rokok melebihi besarnya pengeluaran untuk sayuran, buah, susu atau pangan yang bergizi lainnya. Pada Tabel 3 dapat dilihat pengeluaran pangan rumah tangga petani kopi terbesar dibelanjakan untuk pangan pokok sebesar Rp567.621,43 (24,96\%) dari total pengeluaran pangan dan lauk-pauk sebesar Rp410.014,29 $(18,03 \%)$ dari total pengeluaran pangan yang diperoleh dari membeli dan ada yang tidak membeli.

Pengeluaran nonpangan akan mempengaruhi total pengeluaran rumah tangga. Pengeluaran non pangan terbesar adalah pengeluaran untuk uang saku anak sekolah sebesar 405,942.86 (10,83\%) dari total pengeluran rumah tangga. Pada Tabel 4, dapat dilihat rata-rata pengeluaran pangan rumah tangga petani kopi dalam satu bulan adalah sebesar Rp2.273.890,00 (60,68\%) dari total pengeluaran rumah tangga, sedangkan rata-rata pengeluaran non pangan rumah tangga adalah sebesar Rp1.473.215,48 (39,32\%) dari total pengeluaran rumah tangga. Hal ini menunjukkan bahwa pengeluaran pangan sebagai pengeluaran terbesar dari seluruh pengeluaran total rumah tangga.
Tabel 3. Pengeluaran pangan rumah tangga petani kopi di Kecamatan Ulu Belu Kabupaten Tanggamus

\begin{tabular}{lrc}
\hline Jenis Pengeluaran & \multicolumn{1}{c}{ Jumlah $(\mathrm{Rp})$} & Persentase $(\%)$ \\
\hline - Pangan Pokok & $567.621,43$ & 24,96 \\
- Lauk-Pauk & $410.014,29$ & 18,03 \\
- Kacang-Kacangan & $28.767,86$ & 1,27 \\
- Sayuran & $168.821,43$ & 7,42 \\
- Buah-buahan & $96.778,57$ & 4,26 \\
- Lemak & $97.514,29$ & 4,29 \\
- Makanan Jajanan & $160.528,57$ & 7,06 \\
- Minuman & $144.892,86$ & 6,37 \\
- Bumbu & $197.965,00$ & 8,71 \\
- Rokok & $400.985,71$ & 17,63 \\
\hline Jumlah & $2.273 .890,00$ & 100,00 \\
\hline
\end{tabular}

Ketersediaan pangan dicerminkan dari pangsa pengeluaran pangan rumah tangga yang terdiri dari dua kategori, yaitu tinggi dan rendah. Pangsa pengeluaran tinggi menggambarkan ketersediaan pangan yang belum cukup, sedangkan pangsa pengeluaran rendah menggambarkan ketersediaan pangan yang cukup (Purwaningsih 2008).

Hasil penelitian berdasarkan kriteria BPS pada Tabel 5 menunjukkan sebanyak 61,43 persen rumah tangga petani kopi memiliki pangsa pengeluaran yang rendah. Pangsa pengeluaran yang rendah mengindikasikan pendapatan rumah tangga cukup tinggi, sedangkan pangsa pengeluaran yang tinggi mengindikasikan pendapatan rumah tangga rendah. Rumah tangga berpendapatan tinggi berarti memiliki daya beli yang lebih tinggi untuk memenuhi kebutuhan pangan daripada rumah tangga berpendapatan rendah.

Tabel 4. Total pengeluaran rumah tangga petani kopi di Kecamatan Ulu Belu Kabupaten Tanggamus

\begin{tabular}{lrc}
\hline \multicolumn{1}{c}{ Keterangan } & Jumlah $(\mathrm{Rp})$ & Persentase $(\%)$ \\
\hline Pangan & $2.273 .890,00$ & 60,68 \\
Non Pangan & & \\
- Bahan bakar & $289.057,14$ & 7,71 \\
- Biaya sekolah & $87.059,52$ & 2,32 \\
- Uang saku & $405.942,86$ & 10,83 \\
- Pakaian & $81.005,95$ & 2,16 \\
- Kesehatan & $24.714,29$ & 0,66 \\
- Arisan & $284.285,71$ & 7,59 \\
- Komunikasi & $79.657,14$ & 2,13 \\
- Sabun & $116.635,71$ & 3,11 \\
- Kecantikan & $75.428,57$ & 2,01 \\
- Sumbangan & $29.428,57$ & 0,79 \\
Total pengeluaran non & $1.473 .215,48$ & 39,32 \\
pangan & & 100,00 \\
\hline Jumlah & $3.747 .105,48$ & \\
\hline
\end{tabular}


Tabel 5. Pangsa pengeluaran pangan rumah tangga petani kopi di Kecamatan Ulu Belu Kabupaten Tanggamus

\begin{tabular}{ccccc}
\hline \multirow{2}{*}{ Kategori } & \multicolumn{2}{c}{ BPS } & \multicolumn{2}{c}{ UU Pangan Tahun 2012} \\
\cline { 2 - 5 } & $\begin{array}{c}\text { Jumlah } \\
(\mathrm{n})\end{array}$ & $(\%)$ & $\begin{array}{c}\text { Jumlah } \\
(\mathrm{n})\end{array}$ & $(\%)$ \\
\hline $\begin{array}{c}\text { Rendah } \\
<60 \%\end{array}$ & 43 & 61,43 & 64 & 91,43 \\
$\begin{array}{c}\text { Tinggi } \\
\geq 60 \%\end{array}$ & 27 & 38,57 & 6 & 8,57 \\
\hline Jumlah & 70 & 100,00 & 70 & 100,00 \\
\hline
\end{tabular}

\section{Distribusi (akses) pangan}

Distribusi pangan merupakan salah satu subsistem ketahanan pangan yang memiliki peranan strategis. Subsistem ini mencakup akses pangan secara fisik, ekonomi dan sosial atas pangan secara merata dan berkelanjutan. Rumah tangga petani kopi tidak memiliki akses langsung secara fisik terhadap bahan pangan pokok beras karena tidak melakukan kegiatan produksi, namun rumah tangga petani kopi memiliki akses langsung terhadap beberapa komoditas tanaman pangan seperti sayuran dan buah-buahan serta pangan hewani.

Akses secara ekonomi rumah tangga petani kopi terhadap bahan pangan cukup baik karena berdasarkan hasil penelitian bahan pangan tersedia di pasar, kios, atau toko di lokasi penelitian dengan harga yang terjangkau. Hal tersebut sejalan dengan penelitian Delly, Prasmatiwi dan Prayitno (2019) bahwa rumah tangga tidak memiliki akses langsung secara fisik terhadap bahan pangan pokok namun akses untuk mendapatkan bahan pangan pokok dan komoditas pertanian lainnya cukup mudah dengan harga yang terjangkau.

\section{Konsumsi pangan}

Tingkat kecukupan energi rumah tangga diperoleh dari penghitungan konsumsi energi riil rumah tangga dibagi dengan angka kecukupan energi yang dianjurkan berdasarkan jenis kelamin, usia, dan berat badan seluruh anggota dalam satu rumah tangga. Sebagian besar rumah tangga telah mengonsumsi energi lebih dari 80 persen dari AKE yaitu sebesar $(54,29 \%)$ sedangkan sisanya $(45,71 \%)$ rumah tangga mengonsumsi kurang atau sama dengan 80 persen dari AKE. Rata-rata konsumsi energi per kapita sebesar 2.538,40 kkal, konsumsi tersebut lebih tinggi dibandingkan dengan angka kecukupan energi yang dianjurkan dalam WNPG X tahun 2012 yaitu sebesar 2.150 $\mathrm{kkal} / \mathrm{kapita} / \mathrm{hari}$.
Tabel 6. Sebaran Tingkat kecukupan energi dan protein rumah tangga petani kopi di Kecamatan Ulu Belu Kabupaten Tanggamus

\begin{tabular}{llcc}
\hline Indikator & Kategori & Jumlah (n) & $\begin{array}{c}\text { Proporsi } \\
(\%)\end{array}$ \\
\hline Energi & & & \\
\hline$>80 \%$ & Cukup & 38 & 54,29 \\
$\leq 80 \%$ & Kurang & 32 & 45,71 \\
\hline Jumlah & & 70 & 100,00 \\
\hline Protein & & & \\
\hline$\geq 80 \%$ & Cukup & 59 & 84,29 \\
$<80 \%$ & Kurang & 11 & 15,71 \\
\hline Jumlah & & 70 & 100,00 \\
\hline
\end{tabular}

Berdasarkan penghitungan dari rata-rata konsumsi riil protein dibagi dengan AKP yang dianjurkan bagi rumah tangga berdasarkan jenis kelamin, usia dan berat badan anggota rumah tangga diperoleh rata-rata TKP rumah tangga petani kopi sebesar 146,37 sehingga dapat dikatakan bahwa rumah tangga petani kopi tidak kekurangan asupan protein. Menurut WNPG (2012), kekurangan asupan protein terjadi apabila asupan protein $<80$ persen.

\section{Analisis Tingkat ketahanan pangan}

Berdasarkan hasil analisis tingkat ketahanan pangan rumah tangga petani kopi menggunakan indikator klasifikasi silang yang dikembangkan Jonsson dan Toole dan diadopsi oleh Maxwell et al. (2000), antara pangsa pengeluaran pangan dan kecukupan energi dapat dilihat pada Tabel 7 . Tingkat ketahanan pangan dikategorikan menjadi empat tingkatan yaitu tahan, kurang, rentan dan rawan pangan. Hasil analisis berdasarkan kriteria BPS menunjukkan sebagian besar rumah tangga petani kopi $(31,43 \%)$ tergolong dalam kategori tahan pangan sedangkan berdasarkan kriteria Undang-undang Pangan tahun 2012 sebesar (50\%) tergolong dalam kategori tahan pangan.

Tabel 7. Sebaran tingkat ketahanan pangan rumah tangga petani kopi di Kecamatan Ulu Belu Kabupaten Tanggamus

\begin{tabular}{lcccr}
\hline \multirow{2}{*}{$\begin{array}{c}\text { Tingkat } \\
\text { Ketahanan }\end{array}$ Pangan } & \multicolumn{2}{c}{ BPS } & \multicolumn{3}{c}{ UU Pangan tahun } \\
\cline { 2 - 5 } & $\begin{array}{c}\text { Jumlah } \\
\text { (n) }\end{array}$ & \multirow{2}{*}{$(\%)$} & $\begin{array}{c}\text { Jumlah } \\
(\mathrm{n})\end{array}$ & \multirow{2}{*}{$(\%)$} \\
\hline Rawan pangan & 11 & 15,71 & 2 & 2,86 \\
Rentan pangan & 16 & 22,86 & 4 & 5,71 \\
Kurang pangan & 21 & 30,00 & 29 & 41,43 \\
Tahan pangan & 22 & 31,43 & 35 & 50,00 \\
\hline Jumlah sampel & 70 & 100,00 & 70 & 100,00 \\
\hline
\end{tabular}


Berdasarkan hasil penelitian, menurut kriteria BPS mayoritas rumah tangga petani kopi responden tergolong dalam kategori tahan pangan yaitu sebesar $(31,43 \%)$. Hal ini menunjukkan bahwa tingkat konsumsi energi rumah tangga cukup dan memiliki pangsa pengeluaran pangan yang rendah, sehingga mengindikasikan bahwa pendapatan rumah tangga relatif tinggi dengan diasumsikan harga pangan stabil dan tingkat konsumsi tetap.

Keadaan tersebut menunjukkan bahwa rumah tangga telah mengalokasikan pendapatannya dengan baik untuk mencukupi kebutuhan pangan harian khususnya sumber energi. Berbeda dengan daerah penelitian lain yaitu di Kecamatan Gading Rejo Kabupaten Pringsewu pada kriteria BPS mayoritas rumah tangga petani tergolong dalam kategori rentan pangan sebab pada daerah ini pendapatan petani kurang dan petani tidak memiliki pekerjaan tambahan sehingga daya beli untuk belanja pangan rendah (Fitriani, Prasmatiwi dan Adawiyah 2019).

Kategori rumah tangga rentan pangan menunjukkan bahwa rumah tangga rentan telah berhasil mencukupi kebutuhan energi hariannya, akan tetapi memiliki pangsa pengeluaran pangan yang tinggi, sehingga mengindikasikan bahwa rumah tangga tersebut memiliki pendapatan yang relatif rendah, maka sebagian besar pendapatannya dikeluarkan untuk belanja pangan. Pendapatan yang rendah mengakibatkan daya beli dan akses rumah tangga terhadap pangan rendah, sehingga meskipun ketersediaan pangan mencukupi, rumah tangga petani kopi rentan mengalami rawan pangan, jika pendapatan yang diterima berkurang.

Kategori rumah tangga rawan pangan menunjukkan bahwa rumah tangga rawan pangan memiliki pangsa pengeluaran tinggi, dan kebutuhan energi hariannya belum tercukupi. Rawan pangan terjadi karena pendapatan rumah tangga yang relatif rendah, sehingga tidak mampu mengakses pangan sesuai kebutuhan yang mengakibatkan kebutuhan konsumsi energi tidak dapat tercukupi.

Rumah tangga petani kopi tergolong dalam kategori kurang pangan menunjukkan bahwa kebutuhan energi rumah tangga belum tercukupi, tetapi sebenarnya memiliki daya beli dan akses yang tinggi terhadap pangan karena pangsa pengeluaran pangan rendah, mengindikasikan bahwa rumah tangga memiliki pendapatan yang tinggi. Rumah tangga kurang pangan disebabkan rumah tangga tersebut kurang dapat mengalokasikan pendapatannya untuk belanja pangan dengan baik, sehingga pangan yang tersedia dan dikonsumsi masih belum dapat memenuhi anjuran angka kecukupan energi.

5. Analisis faktor-faktor yang memengaruhi ketahanan pangan rumah tangga petani kopi

Variabel terikat (dependent) yang digunakan berupa data kualitatif yang terdiri dari empat tingkatan kategori ketahanan pangan, yaitu tahan pangan, kurang pangan, rentan pangan, dan rawan pangan. Berdasarkan hasil regresi ordinal logit, faktor yang berpengaruh nyata adalah pendapatan rumah tangga petani kopi (X1) dan tingkat pendidikan ibu rumah tangga (X2), sedangkan variabel independen yang tidak berpengaruh nyata yaitu jumlah anggota keluarga (X3), harga beras (X4), harga minyak goreng (X5), harga tepung terigu (X6), harga gula pasir (X7) dan harga telur (X8) dan harga ikan asin (X9).

Hasil regresi ordinal logit secara lengkap dapat dilihat pada Tabel 8. Dari Tabel 8 dapat dilihat bahwa nilai LR index (Pseudo R2) sebesar 0,153, nilai tersebut menjelaskan bahwa sebesar 15,30 persen variasi peluang ketahanan pangan rumah tangga dapat dijelaskan oleh variasi variabel independen X1 sampai dengan X9. Pada Tabel 8 diketahui bahwa nilai probability LR statistik sebesar 0,00 yang menjelaskan bahwa variabel pendapatan rumah tangga petani kopi, tingkat pendidikan ibu rumah tangga, jumlah anggota rumah tangga, harga beras, harga minyak goreng, harga tepung terigu, harga gula pasir, harga telur dan harga ikan asin secara bersama sama berpengaruh nyata terhadap peluang peningkatan ketahanan pangan rumah tangga petani kopi.

Pendapatan rumah tangga petani kopi berpengaruh nyata terhadap peluang rumah tangga untuk mencapai tahan pangan dengan tingkat kepercayaan sebesar 95 persen. Nilai rasio odd sebesar 1,00 menunjukkan bahwa setiap peningkatan pendapatan rumah tangga sebanyak satu-satuan maka peluang rumah tangga untuk tahan pangan meningkat sebesar 1,00 kali.

Koefisien positif menunjukkan bahwa semakin tinggi pendapatan rumah tangga maka akan meningkatkan ketahanan pangan. Hal ini sejalan dengan hasil penelitian (Hernanda, Indriani dan Kalsum 2017) yang menyatakan bahwa pendapatan dapat mempengaruhi tingkat ketahanan pangan, semakin tinggi pendapatan maka ketahanan pangan rumah tangga akan meningkat. 
Tabel 8. Hasil regresi ordinal logit faktor-faktor yang memengaruhi ketahanan pangan

\begin{tabular}{|c|c|c|c|c|}
\hline Variabel & Coef. & Z-Stat & Prob & $\begin{array}{l}\text { Rasio } \\
\text { odds }\end{array}$ \\
\hline $\begin{array}{l}\text { Pendapatan } \\
\text { rumah tangga }\end{array}$ & $7,70 \mathrm{E}-07 * *$ & 2,01 & 0,04 & 1,00 \\
\hline $\begin{array}{l}\text { Pendidikan ibu } \\
\text { rumah tangga }\end{array}$ & $0,35 * * *$ & 2,60 & 0,01 & 1,42 \\
\hline $\begin{array}{l}\text { Jumlah anggota } \\
\text { rumah tangga }\end{array}$ & 0,13 & 0,41 & 0,68 & 1,14 \\
\hline Harga beras & 0,00 & $-1,22$ & 0,22 & 1,00 \\
\hline $\begin{array}{l}\text { Harga minyak } \\
\text { goring }\end{array}$ & 0,00 & 0,50 & 0,62 & 1,00 \\
\hline Harga terigu & 0,00 & 0,56 & 0,58 & 1,00 \\
\hline Harga gula & 0,00 & 0,43 & 0,67 & 1,00 \\
\hline Harga telur & 0,00 & 0,83 & 0,40 & 1,00 \\
\hline Harga ikan asin & 0,00 & $-0,06$ & 0,95 & 1,00 \\
\hline LIMIT_2:C(10) & 13,33 & 18,51 & 0,96 & 0,34 \\
\hline LIMIT_3:C(11) & 14,95 & 18,47 & 1,07 & 0,28 \\
\hline LIMIT_4:C(12) & 16,74 & 18,47 & 1,20 & 0,23 \\
\hline Pseudo R-squared & & & & 0,15 \\
\hline LR statistic & & & & 29,14 \\
\hline Prob (LR statistic) & & & & 0,00 \\
\hline
\end{tabular}

Tingkat pendidikan ibu rumah tangga petani kopi berpengaruh nyata terhadap peluang rumah tangga untuk mencapai tahan pangan dengan tingkat kepercayaan sebesar 99 persen. Nilai rasio odd sebesar 1,42 menunjukkan bahwa setiap terjadi peningkatan tingkat pendidikan ibu rumah tangga maka peluang rumah tangga petani kopi untuk tahan pangan semakin meningkat. Koefisien positif menunjukkan bahwa semakin tinggi tingkat pendidikan ibu rumah tangga maka akan meningkatkan ketahanan pangan. Hasil penelitian ini sejalan dengan hasil penelitian Yuliana, Zakaria, dan Adawiyah (2013) yang menyatakan bahwa tingkat pendidikan ibu rumah tangga mempengaruhi tingkat ketahanan pangan.

6. Upaya untuk meningkatkan atau mempertahankan ketahanan pangan

Upaya yang dilakukan dalam meningkatkan atau mempertahankan ketahanan pangan rumah tangga petani kopi di Kecamatan Ulu Belu terdiri dari berbagai kegiatan dan program berbeda. Upaya yang dilakukan oleh pemerintah di lokasi penelitian terdiri dari kegiatan pemantauan ketersediaan pangan dan cadangan pangan serta pengembangan distribusi dan stabilitas harga pangan, pengembangan penganekaragaman konsumsi dan keamanan pangan, pengembangan infrastruktur serta bantuan pangan pokok melalui program Raskin. Upaya yang dilakukan oleh rumah tangga petani kopi yaitu dengan meningkatkan pendapatan dengan cara melakukan kegiatan di luar usahatani kopi. Hasil penelitian ini sejalan dengan penelitian Delly et al. (2019) yang menyatakan bahwa upaya yang dilakukan oleh rumah tangga untuk meningkatkan ketahanan pangan yaitu dengan melakukan pekerjaan lain agar memperoleh penghasilan tambahan guna mencukupi kebutuhan pangan.

\section{KESIMPULAN}

Berdasarkan hasil penelitian, dapat disimpulkan bahwa sebagian besar rumah tangga petani kopi di Kecamatan Ulu Belu Kabupaten Tanggamus menurut BPS tergolong dalam kategori tahan pangan 31,43 persen , sisanya 30,00 persen rumah tangga tergolong dalam kategori kurang pangan, 22,86 persen rumah tangga tergolong dalam kategori rentan pangan, dan 15,71 persen rumah tangga tergolong dalam kategori rawan pangan. Rumah tangga tahan pangan menurut kategori Undang-undang Pangan tahun 2012 sebanyak 50,00 persen, kurang pangan 41,43 persen, rentan pangan 5,71 persen dan rawan pangan sebesar 2,86 persen. Faktor yang memengaruhi tingkat ketahanan pangan rumah tangga petani kopi adalah pendapatan rumah tangga petani kopi dan tingkat pendidikan ibu rumah tangga. Upaya yang dilakukan oleh pemerintah di lokasi penelitian terdiri dari kegiatan pemantauan ketersediaan pangan dan cadangan pangan serta pengembangan distribusi dan stabilitas harga pangan, pengembangan penganekaragaman konsumsi dan keamanan pangan dan raskin. Upaya dari rumah tangga petani kopi yaitu dengan meningkatkan pendapatan dengan cara melakukan kegiatan diluar usahatani kopi agar dapat memperoleh penghasilan tambahan untuk membeli pangan dalam memenuhi kebutuhan sehari-harinya.

\section{DAFTAR PUSTAKA}

Anggraini M, Zakaria WA, dan Prasmatiwi FE. 2014. Ketahanan pangan rumah tangga petani kopi di Kabupaten Lampung Barat. Jurnal Ilmu Ilmu Agribisnis, 2(2): 124-132. https://jurnal.fp.unila.ac.id/index.php/JIA/artic le/view/737. [28 April 2018].

Badan Pusat Statistik Provinsi Lampung. 2017. Luas Areal Tanam dan Produksi Komoditas Kopi Menurut Kabupaten di Provinsi lampung Tahun 2016. https://lampung.bps.go.id/dynamictable/2017/ 03/29/143/luas-areal-tanaman-kopi robustaperkebunan-rakyat-menurut kabupaten-kota- 
di-provinsi-lampung-2014-hektar-.html. [25 November 2017].

Delly DP, Prasmatiwi FE, dan Prayitno RT. 2019. Tingkat ketahanan pangan rumah tangga nelayan di Desa Sukajaya Lempasing Kecamatan Teluk Pandan Kabupaten Pesawaran. Jurnal Ilmu Ilmu Agribisnis, 7(2): 141-148.

https://jurnal.fp.unila.ac.id/index.php/JIA/artic le/view/3373/0. [28 Januari 2020].

Fitriani MI, Prasmatiwi FE, dan Adawiyah R. 2019. Ketahanan pangan rumah tangga petani anggota lumbung di kecamatan Gading Rejo Kabupaten Pringsewu. Skripsi. Fakultas Pertanian. Universitas Lampung. Bandar lampung.

Hernanda ENP, Indriani Y, Kalsum U. 2017. Pendapatan dan ketahanan pangan rumah tangga petani padi di Desa Rawan Pangan. Jurnal Ilmu Ilmu Agribisnis, 5(3): 283-291. https://jurnal.fp.unila.ac.id/index.php/JIA/artic le/view/1641.unila.ac.id/index.php/JIA/article/ view/. [28 Januari 2020].

Maxwell D Mc L, Klemeser MA M, Morris S, and Aliadeke C. 2000. Urban Livelihoods and Food Nutrition Security in Greater Accra, Ghana. IFPRI in Collaborative with Noguchi Memorial for Medical Researce and World Health Organization, Researce Report No.112. Washington,D.C.

Perdana dan Hardinsyah. 2013. Analisis jenis, jumlah dan mutu gizi konsumsi sarapan anak Indonesia. Jurnal Gizi dan Pangan, 8(2): 3946. http://journal.ipb.ac.id/index. php/jgizipangan/article/download/7251/5663. [25 Agustus 2020].

Purwaningsih Y. 2008. Ketahanan pangan: pituasi, permasalahan, kebijakan, dan pemberdayaan masyarakat. Jurnal Ekonomi Pembangunan, 9(1): 17-18. FE UNS. Surakarta. http://mesp.fe.uns.ac.id/media/ Ketahanan\%20Pangan\%202008.pdf. [26 September 2019].

Saputri R, Lestari LA, dan Susilo J. 2016. Pola konsumsi pangan dan tingkat ketahanan pangan rumah tangga di Kabupaten Kampar Provinsi Riau. Universitas Gajah Mada. Jurnal Gizi Klinik Indonesia, 12(3): 123-130. [4 November 2019].

Soegiarto. 2003. Teknik Sampling. PT Gramedia Pustaka Utama. Jakarta.

Sugesti MT, Abidin Z, dan Kalsum U. 2015. Analisis pendapatan dan pengeluaran rumah tangga petani padi di Desa Sukajawa, Kecamatan Bumiratu Nuban, Kabupaten Lampung Tengah. Jurnal Ilmu Ilmu Agribisnis, $\quad 3(3)$ : $251-259$. http://jurnal.fp.unila.ac.id/index.php/JIA/articl e/view/1049/954. [28 Januari 2020].

Widyakarya Nasional Pangan dan Gizi (WNPG). 2012. LIPI. Jakarta.

Yuliana P, Zakaria WA., dan Adawiyah R. 2013. Ketahanan pangan rumah tangga nelayan di Kecamatan Teluk Betung Selatan Kota Bandar Lampung. Jurnal Ilmu Ilmu Agribisnis, $\quad 1(2)$ : 181-186. http://jurnal.fp.unila.ac.id/index.php/JIA/articl e/view/246/245. [28Januari2020] 